\title{
Teachers' Competence and Students' Academic Performance in Mathematics: A Brief Cross-sectional Case in Don Mariano Marcos Memorial State University, Philippines
}

\author{
Nora A. Oredina*, Rachelle D. Ebueza \\ College of Education, Don Mariano Marcos Memorial State University, Bacnotan, Philippines
}

Received August 26, 2020; Revised November 7, 2020; Accepted November 19, 2020

\begin{abstract}
Cite This Paper in the following Citation Styles
(a): [1] Nora A. Oredina, Rachelle D. Ebueza, "Teachers' Competence and Students' Academic Performance in Mathematics: A Brief Cross-sectional Case in Don Mariano Marcos Memorial State University, Philippines," Universal Journal of Educational Research, Vol. 8, No. 12A, pp. 7766 - 7774, 2020. DOI: 10.13189/ujer.2020.082564.
\end{abstract}

(b): Nora A. Oredina, Rachelle D. Ebueza (2020). Teachers' Competence and Students' Academic Performance in Mathematics: A Brief Cross-sectional Case in Don Mariano Marcos Memorial State University, Philippines. Universal Journal of Educational Research, 8(12A), 7766 - 7774. DOI: 10.13189/ujer.2020.082564.

Copyright $\bigcirc 2020$ by authors, all rights reserved. Authors agree that this article remains permanently open access under the terms of the Creative Commons Attribution License 4.0 International License

\begin{abstract}
This study determined the relationship of teachers' competence in instruction, research and extension and the students' math performance and its predictors as basis to improve Mathematics instruction. It made use of a descriptive correlational approach with eight mathematics teacher respondents and 151 students major in Mathematics in the College of Education for the SY 2016-2017. Questionnaire was used to gather the data while Pearson $r$ and regression analysis were used to determine relationship and predictors. The teachers are highly competent in instruction with a median of 4 but are competent in research with a median of 3 and in extension with a median of 3. Mathematics majors have very good performance in Mathematics and they are best in Linear Algebra and Technology in Mathematics. The instruction, research and extension competence of teachers are not significantly correlated with the students' Mathematics performance. The competence in instruction, research and extension are not predictors of the performance in Mathematics with $\mathrm{y}=93.86-0.219 \times 1+0.143 \times 2+0.181 \times 3$ as the regression model. The competence of the teacher in instruction, research and extension may not necessarily determine the Mathematics performance of students.
\end{abstract}

Keywords Academic Performance, Competence, Mathematics, Students, Teachers

\section{Introduction}

Teaching is such a very challenging endeavor to anyone who is ready to face it. Thus, we should often take reflection into it [1]. One should not depend only on the knowledge he obtained from college but he must have the burning and strong desire to continue growing professionally so that he will be more equipped with the necessary skills, knowledge and attitudes he needs in his profession. Indeed, a lot of critical factors must be regarded in the teaching profession including those essential implications for professional development and life-long learning [2].

In a narrower sense, tertiary education, which consists of general education courses, subject content and professional subjects, is intended for specialized study to qualify the individual for professional activity for employment in higher positions in business, industry and government. Towards this end, colleges and universities provide necessary training for individuals wishing to enter professional careers. They also strive to develop the students' creativity, insight and analytical skills. Moreover, they provide unique opportunities for personal enrichment 
while also preparing the students for future careers. Putting all these together, tertiary education provides a country's involvement in a knowledge-based world economy imposing its concrete significance in many aspects of life [3].

Mathematics is one of the most important subjects in tertiary education. Hence, it is necessary to ensure that Math teachers are competent enough for them to identify and provide the most important mathematical competencies that students should know [4]. Mathematics plays a vital role in the development of individuals by providing powerful theoretical and computational techniques to advance their understanding of the modern world and societal concerns and to develop and manage the technology industries for the advancement of the national economy. In short, Mathematics is a language of science that is used to solve many real-world problems [5].

Teachers play a critical role in student learning and achievement. Competencies are the skills and knowledge that enable a teacher to be successful. To maximize student learning, teachers must have expertise and skills in instruction, research and extension. Research confirms that of all factors under the control of a school, teachers are the most powerful influence on student success.

Competent teachers are the most influential factor in bringing high students' achievement. The teachers greatly influence the students' performance through their abilities, potentialities and professional competence. Only competent teachers can bring desired learning among their students. [6]

A research on teacher quality states that effective teachers make students enjoy learning while increasing their student achievements. Many studies discovered that personal and professional qualities are directly proportional to the levels of students' achievement. [7]

Another research revealed that the competent teacher is the one who effectively and efficiently teaches in the classroom using appropriate competencies and skills. He is accountable for students' learning and providing friendly learning environment. He provides clear explanations, adequate examples, conducts researches to improve teaching and learning and forging linkages and involvement to the society to get the latest trends and innovation for the enhancement of teaching and learning. [8]

A researcher opined that to attain high students' achievement is to provide effective teachers. Students' performance is indicative of teachers' performance. Relative to this, students' academic result is considered a main source for teachers' evaluation. [9]

Another research also mentioned that teacher quality is the foremost factor affecting students' performance. If the teachers are highly competent, there is a high probability that effective learning will take place. [10]

Moreover, another research disclosed that there is a significant relationship between students' achievement and professional competence of teachers. This implies that the teachers' competence has a strong effect on students' performance. [11]

These research findings serve as the basis of conducting the study. It aimed to verify if these findings are also true for the case of the Mathematics teachers.

In La Union, Philippines, quality Mathematics teaching in colleges and universities has been given much emphasis. Seminars are conducted regularly so as to update the Mathematics teachers on the latest trends, practices and innovative teaching techniques. There are also several publications that tackle Mathematics-related learning investigations [12] [13]. However, sometimes, these activities involve only a minority of the Mathematics teachers. It is a felt need to appraise and evaluate the competence of Mathematics teachers along instruction, research and extension. These are considered the trilogic functions of college instructors and to determine if they are correlated and can predict students' performance in Mathematics is worth delving. The result of which can now serve as a basis in devising activities which will improve Mathematics instruction.

This study would be beneficial to stakeholders who will cooperate and contribute to having a better, high-quality Mathematics instruction. To the practitioners of educational management as a discipline, this study provides insights into the indicators of faculty performance along profile, efficiency rating and students' academic performance as essential inputs when crafting an action plan designed to address the identified needs. To the academic administrators, especially those responsible for recruiting, hiring, and honing the efficiency of the faculty, this study provides a keener understanding on what makes a strong, capable, competent, and dependable faculty. In particular, the proposed action plan, once approved by top management, serves as a roadmap at least during its implementation period for focused efforts of the institution to provide a fuller complement of faculty members with improved performance. To faculty members, this study gives better knowledge on the essential measures of one's performance of his responsibilities as an educator, imbibed with the clearer understanding of his contributions as a key player in the realization of an institution's philosophy, vision, goal, mission and objectives, particularly of the importance of his cooperation to ensure the success of the implementation of the proposed action plan. To the students, the results of this study including the proposed action plan will redound to their best interest and welfare. An improved professional profile and enhanced efficiency of the faculty is translated to better instruction. To the researchers, this study will serve as an eye opener on the status of the faculty relative to professional profile and efficiency rating, enable them to analyze and correlate the various indicators and determinants of faculty and 
students' performance, and provide them an assessment of needs for further improving the instruction of the College of Education. To future researchers, the results of this study may serve as a model in conducting similar and/or parallel studies, including the formulation of an action plan. We see how encompassing Mathematics is. We see how it is used by everyone, even to the everyday life of ordinary people [13].

Therefore, this study aimed to determine the level of competence of teachers along instruction, research and extension; students' level of academic performance and predictors of students' performance. Specifically, it sought to attain the following objectives:

1. Determine level of competence of Mathematics teachers along instruction, research and extension.

2. Determine the level of students' academic performance in Mathematics.

3. Establish if there is a relationship between teachers' competence and students' performance in Mathematics.

4. Assess the predictors of performance in Mathematics.

\section{Materials and Methods}

This study utilized the descriptive method of investigation. This is best fitted to the study because this method involves describing, recording, analyzing and interpreting conditions that exist. It also included relationship between existing non-manipulative variables. It also used quantitative approach. Hohmann [14] defines quantitative research approach as a type of descriptive design making use of numerical data. Its main purpose is to analyze input variables using quantitative techniques such as means, percentages, ranking etc. This approach is appropriate for this study since it makes use of quantitative techniques to determine the profile of the Math teachers, the competence along instruction, research and extension and performance of students as well as the relationships of the said variables.

The respondents were Mathematics teachers in the College of Education in the DMMMSU-NLUC for the first semester of SY 2016-2017. There were eight Mathematics teachers and 151 students specializing in Mathematics. Questionnaire and documentary analysis were used as data gathering tools. The questionnaire was lifted from the study of Cristobal [15] on the competence of teachers along instruction, research and extension. The questionnaire makes use of Likert scale from 1 to 4 . The competence of teachers along instruction includes indicators such as teachers' personal characteristics and teaching efficiency. Specific indicators under each variable are included. Under teaching efficiency, the teachers are rated on several indicators along methods and techniques of teaching, motivation for learning and critical reflection, general atmosphere in class, substantiality of teaching and evaluation skills.

Along teachers' personal characteristics, the specific indicators are clarity and modulation of voice, maintenance of self-control both in action and words and fluency and explanation of the lesson using the language of instruction.

For teaching efficiency, under methods and techniques, the specific indicators are: presentation of the subject matter is well organized and logical, explanation of the subject matter is clear and accurate, utilize varied materials, technology and instructional aids in teaching and utilize varied teaching techniques, strategies and activities. Moreover, for the motivation for learning and critical reflection, the specific indicators are: present the lesson in an interesting and enthusiastic manner, encourage students' participation, appreciate desirable behavior, give activities which stimulate intellectual curiosity and critical thinking and relate lesson to real life and integrate values.

Meanwhile, for the general atmosphere in class, the specific indicators are: manifest pleasant atmosphere conducive for learning, maintain discipline among students, implement school policies among students and teach without annoying mannerism and/or verbal behavior that distracts students from learning. Furthermore, for the substantiality of teaching, the specific indicators are: show mastery of the subject matter, incorporated recent developments in the lesson, present important of the subject matter, present the lesson to gain an in-depth knowledge of the subject matter and relate lesson to other fields and connect to the profession.

Lastly, the indicators under evaluation skills along appraisal question are: ask thought provoking questions, follow up answers and reactions, ask questions leading to synthesis or summary of the salient points of the lesson, prepare well-framed test questions which are valid and reliable. Along assigned enrichment activities, the specific indicators are: give assignment to enrich and supplement what is taken in class, give course requirements that are practical and challenging and give adequate time for students to complete assigned course requirements. Along the conduct and return of evaluation materials, the indicators are: vigilant in conducting quizzes' exams to avoid cheating, efficient in checking test papers, quizzes and other course requirements, return corrected test papers, quizzes and written requirements within two weeks and inform students specific area of improvement. Similarly, indicators under each skill in research and extension were also considered and the faculty members were rated along those indicators.

The profile variables were just included in the questionnaire. Because the tool is lifted from a previous study, its validity and reliability are assumed. The performances of students in Mathematics were taken from the grading sheets of the teachers. For the analysis of data, 
median was used to determine the competence of teachers along instruction, research and extension. Since the data gathering instrument is a Likert scale, it produces an ordinal data. They have inherent order or sequence. The median is the most appropriate tool to use. The median is a measure of central tendency which shows what the respondent might think.

Pearson $r$ is used to determine the relationship between variables while regression analysis was utilized to determine predictors of students' performance. Data analysis toolpak was used to facilitate the treatment of data. The scale below is used to categorize the competence of teachers:

\begin{tabular}{|c|c|c|}
\hline Point Scale Value & Description & Code \\
\hline $3.26-4.00$ & Highly Competent & HC \\
\hline $2.51-3.25$ & Competent & C \\
\hline $1.76-2.50$ & Fairly Competent & FC \\
\hline $1.51-1.75$ & Not Competent & NC \\
\hline
\end{tabular}

The scale below is used to categorize the performance of the students in Mathematics:

\begin{tabular}{|c|c|}
\hline Range of Grades & Description \\
\hline $96-100$ & Outstanding \\
\hline $89-95$ & Very Good \\
\hline $82-88$ & Good \\
\hline $75-81$ & Fair \\
\hline Below 75 & Poor \\
\hline
\end{tabular}

The scales of interpretation on the degree of relationship of the identified correlates are as follows:

\begin{tabular}{|c|c|}
\hline Degree of Relationship & Description \\
\hline $0.00-0.10$ & Very Low Correlation \\
\hline $0.11-0.30$ & Low Correlation \\
\hline $0.31-0.70$ & Marked/ Substantial \\
\hline $0.71-0.90$ & High Correlation \\
\hline $0.91-0.99$ & Very High Correlation \\
\hline
\end{tabular}

\section{Results and Discussion}

\section{Level of Competence of Math Teachers along Instruction, Research and Extension}

Table 1 presents multiple indicators to gauge the level of competence of Mathematics teachers along instruction. The table shows a high level of competence of Math teachers with a median of 4. They are highest in motivation and in teaching efficiency but poorest in substantiality of teaching. The high competence of teachers implies that they are highly equipped with teaching skills to make instruction highly effective. Regarding personal characteristics, the math teachers are highly competent. They excel in maintaining self-control both in action and words. They talk clearly and are easily understood. They have well-modulated voice and mastery of the language used for instruction. On teaching efficiency, they are best in motivating and in developing critical reflection with a median of 4 . In short, the teachers are highly capable of sustaining students' interest. They also enjoin participation and students' involvement. They also stimulate curiosity and develop critical thinking.

Table 1. Level of competence of math teachers along instruction

\begin{tabular}{|c|c|c|}
\hline INDICATORS & Median & $\begin{array}{l}\text { Descriptive } \\
\text { Rating }\end{array}$ \\
\hline I. Teacher's Personal Characteristics & 4.00 & $\mathrm{HC}$ \\
\hline \multicolumn{3}{|l|}{ II. Teaching Efficiency } \\
\hline $\begin{array}{l}\text { 1. Methods and Techniques of } \\
\text { Teaching }\end{array}$ & 4.00 & $\mathrm{HC}$ \\
\hline $\begin{array}{l}\text { 2. Motivation for Learning and } \\
\text { Critical Reflection }\end{array}$ & 4.00 & $\mathrm{HC}$ \\
\hline 3. General Atmosphere in class & 4.00 & $\mathrm{HC}$ \\
\hline 4. Substantiality of Teaching & 4.00 & $\mathrm{HC}$ \\
\hline 5. Evaluation Skills & 4.00 & $\mathrm{HC}$ \\
\hline Sub Median & 4.00 & $\mathrm{HC}$ \\
\hline Overall Median & 4.00 & $\mathrm{HC}$ \\
\hline
\end{tabular}

*HC - Highly competent

The mathematics teachers are also highly competent along methods and techniques of teaching with a median of 4. They also discuss the lessons clearly, which results in students' better understanding of the lessons taught. Likewise, they are creative in utilizing varied teaching techniques, strategies and activities such as using instructional materials. For the general atmosphere in class, the math teachers are also highly competent. They are highly capable of providing a conducive learning environment. This also implies that they are excellent in classroom management. They are able to maintain discipline among students. In addition, they teach without distractive mannerisms or extra movements. Along substantiality of teaching, the mathematics teachers are highly competent with a median of 4 . They incorporate trends and innovations in the lesson. They give emphasis to the important aspects of the lesson. They provide deeper analysis of the subject matter producing critical thinking among the students. They are also good at integrating, showing how a specific lesson relates to other fields and professions.

Along evaluation skills, the teachers are also identified to be highly competent with a mean of 4 . This implies that the teachers prepare very good questions for both oral questioning and written examinations. They carefully follow the principles of test construction. Likewise, they administer exams vigilantly to prevent cheating. Similarly, they are prompt in returning assessment results as well as see to it that they are checked appropriately and accurately. They also give reasonable, practical and challenging 
assignments and course requirements. The students are well informed of their rating and they are able to utilize assessment results to improve their performance.

The result of the present study is different with the findings of Barnuevo [16] on Instructional Competencies of the Teaching Force: Their Relationship to the Students' Academic Performance" in which the Mathematics teachers are "Often" practicing the manifesting behaviors of being competent in the instruction which consists of Mastery of the Subject Field, Teaching Skills, Classroom Management and Evaluation Skills. This indicates that the Mathematics teachers are not that competent in instruction.

Determining the competence of Mathematics teachers along instruction has an important social implication. According to Henderson and Rodrigues [17], the educational attainment of learners may be affected by teacher's competence, particularly in Mathematics education. Moreover, they have found out that $95 \%$ of student-respondents perceived that confidence is another salient parameter that affects the competence level of Mathematics teachers. There are other ways that Math teachers' competence along instruction can be improved. Santagata and Yeh [18] discovered the role of perception, interpretation and decision making for Math teachers to reflect about their own teaching and to further develop their teaching competence. Huang and Han [19] suggested that parallel lesson study can be used to develop Mathematics teacher's competence and Oonk et al. [20] recommended the crucial nature of enriching practical knowledge.

Table 2. Level of competence of math teachers along research

\begin{tabular}{|c|c|c|}
\hline Research Competencies & Median & Descriptive Rating \\
\hline Conceptual Skills: & 4 & HC \\
\hline Comprehension Skills: & 3 & C \\
\hline Analytical skills: & 3 & C \\
\hline Technical Skills: & 4 & HC \\
\hline Overall Median & 3 & C \\
\hline
\end{tabular}

*HC - Highly competent

*C - Competent

It can be noted from Table 2 that the math teachers are competent in research with a median of 3 . They are best in conceptual and technical skills but poorest in comprehension and analytical skills. The competence of teachers in research means that they have already embraced research in their culture. They are capable of preparing and completing a research work. They are highly competent in conceptual skills and technical skills with a median of 4 . This means that they are highly skillful and capable of conceptualizing a research proposal. They can identify the problem with corresponding hypothesis, formulate paradigm and complete the theoretical and conceptual framework as well as define the terms operationally. Likewise, they can gather data manually, utilize computer to tally and construct the tables.
They can also write the research report using the accepted format.

Along comprehension skills, they are good in gathering and organizing related literature and in identifying the most appropriate statistical tools. Along analytical skills, they are also capable in summarizing and formulating recommendations. It can be noted though that they are only competent in some skills. This implies that they have not completely developed their competencies along research and hence still need research enhancement program to completely develop all the skills. Along conceptual skills, they are poorest in developing the rationale part. Along comprehension skills, they are less competent in preparing the research design and in developing the data gathering instrument. Along technical skills, they are practically good in all the skills except in treating the data statistically. This is usually the identified weakness of many of the researchers knowing they can simply depend on statisticians to do this part of the research for them. The table indicates that they are only competent along analytical skills. with a median of 3 . This is indicative that they are capable of performing indicated skills but still need more practice to develop the skills to the optimum. They analyze data quantitatively and qualitatively, interpret findings, make implications and corroborate findings with past researches. Likewise, they can draw conclusions and organize their research report.

This is contrary to the statement of Türkmen and Kandemir [21] that teachers lack adequate knowledge on scientific process skills hence students are raised as individuals with low levels of scientific process skills. Echoing results can be traced to the studies conducted by Karsl1, Şahin and Ayas [22], Hazır and Türkmen [23]. Further, teachers lack adequate level of research competencies [24]. They even lack theoretical knowledge on scientific process [25]. This indicates that they perform very poorly in this area of their trilogic functions thus more research capacity-building initiatives are needed to develop their competencies.

Table 3. Level of competence of math teachers along extension

\begin{tabular}{|c|c|c|}
\hline Extension Competencies & $\begin{array}{c}\text { Media } \\
\mathrm{n}\end{array}$ & $\begin{array}{c}\text { Descriptive } \\
\text { Rating }\end{array}$ \\
\hline Situation Analysis & 3.00 & $\mathrm{C}$ \\
\hline Planning Skill & 3.00 & $\mathrm{C}$ \\
\hline Coordinating Skill & 3.00 & $\mathrm{C}$ \\
\hline Implementing Skills & 3.00 & $\mathrm{C}$ \\
\hline Monitoring and Evaluation Skills & 3.00 & $\mathrm{C}$ \\
\hline Overall Median & 3.00 & $\mathrm{C}$ \\
\hline
\end{tabular}

${ }^{*} \mathrm{C}$ - Competent

The Math teachers are competent along their skills in extension with an overall median of 3 (Table 3). They are equally competent in the different skills. Among the extension skills, they are practically competent in planning. In short, they can identify recipients or 
beneficiaries as well as sponsors to finance the program. Similarly, they can conceptualize activities addressing the needs of the beneficiaries. They perform equally in all the other skills like identifying situation analysis, coordinating, implementing and monitoring skills. This elucidates further that they are good in performing these tasks but there is still a room for improvement. They are capable of conducting needs assessment utilizing the most appropriate data gathering materials, they can coordinate with authorities and linkages in the conduct of their extension activities as well as implement, mobilize and monitor their extension programs. In short, they regularly check if their extension programs are working or not.

\section{Level of Academic Performance in Mathematics}

Table 4 discloses that the performance of students in Mathematics is very good with a mean of 88.6. They are highest in linear algebra and technology in Mathematics and lowest in problem solving and instrumentation in Mathematics. The very good academic performance of students clearly shows that students majoring in mathematics are performing well in their major subjects. This is indicative that they have not only acquired the needed skills and competencies but even have mastered them. This also shows that they have the adequate knowledge of Math concepts which they can use later on when they become teachers themselves. It can be noted that they perform best in two major subjects such as Technology in Mathematics and Linear Algebra with a grade of 93. This means that they are highly skilled in using technology in learning Mathematics. The calculator and mathematics software are very easy for them to use and manipulate. Likewise, the concepts of linear algebra are easy for them. They find dealing with matrices interesting.

On the contrary, they are fair only in Calculus I. They perceived calculus as the most difficult subject and they were able to experience difficulties the first time that they had it. Notably they performed very good in Calculus 2 already which implies that they were able to adjust to the ins and outs of the subject. They also have shown slight difficulty in problem solving and in instrumentation in Mathematics. The problem-solving subject required them to apply all the skills and concepts learned in their other Math subjects. They may have forgotten some of the concepts. Along instrumentation, the task is to prepare instructional materials which may still be a little difficult for the math majors since their interest is more on solving and computing. This is in contrast to the result of the study of Barnuevo [16] stating that the academic performance of the students in Mathematics is generally under the scale of average ranging from $80-84$.

Table 4. Level of academic performance in mathematics

\begin{tabular}{|c|c|c|}
\hline Math Subject & Students' Performance & Descriptive Equivalent \\
\hline History of Math & 92 & Very Good \\
\hline Trigonometry & 92 & Very Good \\
\hline Advanced Algebra & 92 & Very Good \\
\hline Solid Geometry & 91 & Very Good \\
\hline Linear Algebra & 93 & Very Good \\
\hline Calculus 2 & 91 & Very Good \\
\hline Abstract Algebra & 92 & Very Good \\
\hline Advanced Statistics & 92 & Very Good \\
\hline Number Theory & 90 & Very Good \\
\hline Analytic Geometry & 89 & Very Good \\
\hline Probability and Statistics & 90 & Very Good \\
\hline Modern Geometry & 88 & Good \\
\hline Seminar in Problem Solving & 83 & Good \\
\hline Instrumentation in Mathematics & 82 & Good \\
\hline Plane Geometry & 84 & Good \\
\hline Calculus 1 & 79 & Fair \\
\hline Teaching Approaches in Mathematics & 87 & Good \\
\hline Math of Investigation and Modeling & 87 & Good \\
\hline Math of Investment & 85 & Good \\
\hline Technology in Mathematics & 93 & Very Good \\
\hline Mean & 88.6 & Very Good \\
\hline
\end{tabular}




\section{Relationship between Variables}

The linearity test is a requirement in the correlation and regression analysis. Using SPSS to test linearity between teachers' competence in instruction and students' performance, the ANOVA output table revealed the value for sig. deviation from linearity which is .715 . This is greater than .05 . It can be concluded that there is a linear relationship between teachers' competence in instruction and students' performance. Similarly, values which are .614 and $.317 \mathrm{sig}$. deviation from linearity are obtained between research competence and students' performance and between extension competence and students' performance, respectively. Therefore, there are also linear relationships between research competence and students' performance and between extension competence and students' performance.

The teachers' competence in instruction, research and extension and students' math performance are not significantly correlated. One of the variables not significantly correlated to academic performance of students is the instruction competence of teachers. This implies that it does not necessarily mean that the higher the instruction competence of teachers, the better the performance of the learners. Better teaching skills may not produce better performance of learners. The same table discloses that there exists no significant relationship between the teachers' research and extension competence and students' performance. This implies that the students' performance cannot be attributed to the competence of teachers in research and extension. Similarly, teachers' competence in research and extension is not contributory to the performance of the learners. Hence, whether the teacher excels in research and extension or not, the students would still have the same performance.

Table 5. Relationship between teachers' competence and students' math performance

\begin{tabular}{|c|c|c|c|}
\hline Variables & $\begin{array}{c}\text { Coefficient of } \\
\text { correlation }\end{array}$ & $\begin{array}{c}\text { Descriptive } \\
\text { Equivalent }\end{array}$ & Remarks \\
\hline $\begin{array}{c}\text { Instruction } \\
\text { and } \\
\text { performance }\end{array}$ & 0.34 & Moderate & $\begin{array}{c}\text { Not } \\
\text { Significant }\end{array}$ \\
\hline $\begin{array}{c}\text { Research and } \\
\text { Performance }\end{array}$ & 0.49 & Substantial & $\begin{array}{c}\text { Not } \\
\text { significant }\end{array}$ \\
\hline $\begin{array}{c}\text { Extension and } \\
\text { Performance }\end{array}$ & 0.65 & Substantial & $\begin{array}{c}\text { Not } \\
\text { significant }\end{array}$ \\
\hline
\end{tabular}

The finding on the correlation between teachers' competence and academic performance of the students is not consistent with the study made by Schacter and Thum [26] which revealed that there is a relationship between competency and academic achievement. They found that teachers who implement effective teaching which is measured by twelve teaching standards (i.e. Teacher Content Knowledge, Lesson Objectives, Presentation, Lesson Structure and Practicing, Activities, Feedback, Questions, Thinking, Grouping Students, Motivating Students, Classroom Environment, and Teacher
Knowledge of Students) produce students who make considerable academic achievement. Moreover, a local study also made by Cancungco et al. [27] found out that the ways of teachers deliver their lessons identify the best practices in teaching the subjects which directly affects students' learning. On the contrary, Barnuevo [16] found out that statistically, instructional competencies of the Mathematics teachers and the students' academic performance in Mathematics $(r=0.221)$ had low correlation. This implies that the academic performance of the students does not depend much on the instructional competencies of the Mathematics teachers.

\section{Predictors of Performance in Mathematics}

Model of the regression equation is $\mathrm{y}=93.86-0.219 \times 1$ $+0.143 \times 2+0.181 \times 3$ where $\mathrm{x} 1, \mathrm{x} 2$ and $\mathrm{x} 3$ are competence in instruction, research and extension respectively. The teachers' competence in instruction, research and extension are not significant predictors of students' academic performance. A study that finds a relationship between observable teacher characteristics and student performance was conducted by Slater, Davies and Burgess [28] to investigate whether the observable characteristics of teachers are correlated with measures of teacher effectiveness. The observable characteristics available are teacher gender, age, educational attainment and teaching experience. The results revealed that none of these characteristics are statistically significant in explaining teacher effectiveness [28]. It is interesting to note, however, that Slater et al. [28] found a correlation (albeit weak) between the ability of students and teacher effectiveness, suggesting non-random allocation of students within a school. Allocating students to teachers in such a way that places less able student with more effective teachers may well enhance the positive impact of teacher effectiveness.

Table 6. Predictors of performance in mathematics

\begin{tabular}{|c|c|c|}
\hline Variables & $\begin{array}{c}\text { P } \\
\text { value }\end{array}$ & Remarks \\
\hline Competence in Instruction & .70 & Not Significant \\
\hline Competence in Research & .71 & Not Significant \\
\hline Competence in Extension & .60 & Not Significant \\
\hline
\end{tabular}

The competence of math teachers in instruction cannot necessarily forecast the performance of students in Mathematics. The study of Endrogan and Sahin [29] negates the finding of the study which revealed that teachers technological pedagogical and content knowledge significantly predicts the students' achievement level which implies that teachers' competence plays an important role in students' achievement.

There is various published literature which is delved with different developmental and psychological parameters to predict achievement in Mathematics. 
Ganley and Vasilyeva [30] presented that spatial skills predicted Mathematics performance in male students but not in female students. Hence sex differences can potentially predict and draw relation between Mathematics performance, spatial skills and attitudes. Interestingly, Caldas [31] pointed out that poverty, race and foreign language immersion can also be good predictors of math performance. Finally, Choi [32] reiterated that self-efficacy and self-concept are predictors of college's students' academic performance, not only in math but across various disciplines. It is then strongly recommended that future studies on teacher-related predictors of students' performance in other subjects like Science and English be conducted. In a much broader sense, the teacher also needs to contemplate on the utilization of synergistic teaching pedagogies to diversify both teacher- and student- centered approaches so that authentic learning will transpire and high-quality education is attained [33].

\section{Conclusions}

The Mathematics teachers possess the necessary skills and competencies in instruction. They are equipped with adequate knowledge in research. They are also capable of conducting extension activities. On the other hand, the Mathematics students show mastery in the different areas of Mathematics but acquired only the minimum skills and competencies in other Math subjects. Hence, academic performance of students cannot be attributed to the competence of teachers in instruction, research and extension. The competence of teachers cannot necessarily forecast the performance of students in Mathematics.

\section{Acknowledgements}

The researchers would like to extend his gratitude to the Don Mariano Marcos Memorial State University for funding this research undertaking.

\section{REFERENCES}

[1] Pedro J., "Taking reflection into the real world of teaching," Kappa delta pi record, vol. 42, no. 3, pp. 129-132, 2006. https://doi.org/10.1080/00228958.2006.10516449.

[2] Nicholls G., "Professional development, teaching, and lifelong learning: the implications for higher education," International journal of lifelong education, vol. 19, no. 4, pp. 370-377, 2000. https://doi.org/10.1080/0260137005011041 9.

[3] World Bank (IBRD), "Constructing knowledge societies: New challenges for tertiary education," 2002. http://hdl.voced.edu.au/10707/64272.
[4] Blum W., Galbraith P. L., Henn H. W., Niss M., "Modelling and applications in mathematics education," New York: Springer, pp. 3-33, 2007. https://doi.org/10.1007/s11858-00 7-0070-z.

[5] Stecke K. E., "Using mathematics to solve some problems in industry," INFORMS Transactions on Education, vol. 5, no. 2, pp 1-8, 2005. https://doi.org/10.1287/ited.5.2.1.

[6] Tope O., "Effects of Teachers' Competence on Students' academic Performance: A case study of Ikeja Local Government area of Lagos state” Ego Booster Books, 2012. egobooster books.files.wordpress.

[7] Tucker P. D., "Teacher quality and student achievement: A Review of state policy evidence," Education policy Analysis Archives, vol. 8, no. 1.

[8] Varvel, C., "Pedagogical Roles and Competencies of University Teachers Practicing in the E-Learning Environment" vol. 14, no. 3 (2013).

[9] Scand, H. E., "Understanding the Pedagogical Discourse of Assessment in Physical Education," Asia-Pacific Journal of Health, Sport and physical Education, Word press, 2013.

[10] Harris J., Mishra P., Koehler M., “Teachers' technological pedagogical content knowledge and learning activity types: Curriculum-based technology integration reframed," Journal of research on technology in education, vol. 41, no. 4, pp. 393-416, 2009. https://en.wikipedia.org/.../Technological_P edagogical_Content_Knowledge.

[11] Naz, K., "Effects of teachers' professional competence on students' academic achievements at secondary school level in Muzaffarabad District, Munich," GRIN Verlag, 2016. https://www.grin.com/document/352095.

[12] Rivera E. A., "Mother tongue-based mathematics Iloko language competence of grade 1 learners in Bauang district, division of La Union," In International Conference on Education, 2017.

[13] Gates P., Vistro-Yu C. P., "Is mathematics for all?. In Second international handbook of mathematics education" Springer, Dordrecht, pp. 31-73, 2003. https://doi.org/10.100 7/978-94-010-0273-8_3.

[14] Hohmann L., "Innovation games: creating breakthrough products through collaborative play," Pearson Education, 2006.

[15] Cristobal J. M., "Capabilities and needs of the College Faculty of Lorma Colleges along instruction, research and extension: A basis for a training program," A Thesis. San Fernando City, La Union, Philippines, 2004.

[16] Barnuevo R. J., "Instructional Competencies of the Teaching Force: Their Relationship to the Students' Academic Performance," (Undergraduate Thesis, Don Bosco College), 2012.

[17] Henderson S., Rodrigues S., "Scottish student primary teachers' levels of mathematics competence and confidence for teaching mathematics: some implications for national qualifications and initial teacher education," Journal of education for Teaching, vol. 34, no. 2, pp. 93-107, 2008. https://doi.org/10.1080/02607470801979533.

[18] Santagata R., Yeh C., "The role of perception, interpretation, and decision making in the development of beginning 
teachers' competence," ZDM, vol. 48, no. 1-2, pp. 153-165, 2016. https://doi.org/10.1007/s11858-015-0737-9.

[19] Huang R., Han X., "Developing mathematics teachers' competence through parallel lesson study," International Journal for Lesson and Learning Studies, 2015. https://doi.org/10.1108/IJLLS-10-2014-0037.

[20] Oonk W., Verloop N., Gravemeijer K. P., "Enriching practical knowledge: Exploring student teachers' competence in integrating theory and practice of mathematics teaching," Journal for Research in Mathematics Education, vol. 46, no. 5, pp. 559-598, 2015. doi.org/10.5951/jresematheduc.46.5.0559.

[21] Türkmen H., Kandemir E. M., "Case study on perceptions of teachers on scientific process skills learning domain," Journal of European Education, vol. 1, no. 1, pp. 15-24, 2011.

[22] Karsli F., Şahin Ç., Ayas A., "Determining science teachers' ideas about the science process skills: A case study," Procedia-Social and Behavioral Sciences, vol. 1, no. 1, pp. 890-895, 2009. https://doi.org/10.1016/j.sbspro.2009.01.15 8.

[23] Hazır A., Türkmen L., "Scientific process skill levels of primary education 5th grade students," Selçuk University Ahmet Keleşoğlu Faculty of Education Journal, vol. 26, pp. 81-96, 2008.

[24] Büyüköztürk Ş., "Research Competencies of primary education teachers. Educational Administration," Theory and Practice, vol. 18, pp. 257-269, 1999.

[25] Türkmen H., Kandemir E. M., "Case study on perceptions of teachers on scientific process skills learning domain," Journal of European Education, vol. 1, no. 1, pp. 15-24, 2011.

[26] Schacter J., Thum Y. M., "Paying for high-and low-quality teaching," Economics of Education Review, vol. 23, no. 4, pp. 411-430, 2004. https://doi.org/10.1016/j.econedurev.20
03.08.002.

[27] Cancungco B.M.M., Yumul, W.R.L., "Teaching Practices of English Teachers for the elementary grades at Angeles Elementary School, Angeles City," Angeles University Foundation, 2005

[28] Slater H., Davies N. M., Burgess S., "Do teachers matter? Measuring the variation in teacher effectiveness in England," Oxford Bulletin of Economics and Statistics, vol. 74, no. 5, pp. 629-645, 2012. https://doi.org/10.1111/j.1468-0084.201 1.00666.x.

[29] Erdogan A., Sahin I., "Relationship between math teacher candidates' technological pedagogical and content knowledge (TPACK) and achievement levels,' Procedia-Social and Behavioral Sciences, vol. 2, no. 2, pp. 2707-2711, 2010. https://doi.org/10.1016/j.sbspro.2010.03. 400 .

[30] Ganley C. M., Vasilyeva M., "Sex differences in the relation between math performance, spatial skills, and attitudes," Journal of Applied Developmental Psychology, vol. 32, no. 4, pp. 235-242, 2011. doi.org/10.1016/j.appdev.2011.04.00 1.

[31] Caldas S. J., "Poverty, Race, and Foreign Language Immersion: Predictors of Math and English," Learning Languages, 1999.

[32] Choi N., "Self - efficacy and self - concept as predictors of college students' academic performance," Psychology in the Schools, 42(2), 197-205, 2005. https://doi.org/10.1002/pits. 20048 .

[33] Aban J. L., Abubo R. P., Sario C. G., "Knowledge, Attitudes, and Practices on the Six Common Teaching Strategies of Tertiary Level Teachers and Students: A Brief Cross Sectional Case Report," The International Journal of Interdisciplinary Educational Studies, vol. 15, no. 2, pp. 83-97, 2020. https://doi.org/10.18848/2327-011X/CGP/v15 i02/83-97. 